\title{
Desaprendemos a comer: e agora, o que fazer?
}

A obesidade é uma doença crônica, multifatorial, caracterizada pelo excesso de gordura corporal. Está relacionada com o aumento do risco para o desenvolvimento de doenças cardiovasculares, diabetes mellitus tipo 2, hipertensão e dislipidemias, dentre outras alterações de ordem física e psicológica. Sua prevalência cresce em todo o mundo e, no Brasil, cerca de $40 \%$ dos adultos e $33 \%$ da população infantil apresenta excesso de peso. Governos, centros de pesquisa e universidades investem dinheiro e conhecimento no intuito de desvendar as causas e o tratamento do mal do século. No entanto, a compreensão desta doença tão complexa deve ir além da abordagem biológica do ser humano. Conhecer as causas sociais, econômicas e culturais, envolvidas na gênese da obesidade é fundamental para desenvolver uma intervenção efetiva.

Neste sentido, é importante considerar que, o aumento da prevalência da obesidade nas últimas décadas, é fruto de profundas mudanças sociais. A maior distribuição de renda e a inserção da mulher no mercado de trabalho afastaram as famílias do hábito de preparar seus próprios alimentos, e estas passaram a consumir mais alimentos industrializados e a realizar mais refeições fora de casa. Além disso, o aumento da violência nos grandes centros urbanos contribuiu para um estilo de vida mais sedentário, principalmente para as crianças, que ficam mais seguras dentro de casa assistindo televisão ou jogando em seus computadores. Em média, as crianças brasileiras dedicam mais horas para assistir televisão do que para frequentar a escola. $E$ é justamente na escola que pode estar uma das saídas deste labirinto chamado obesidade. Em conjunto com a família, a escola pode determinar a formação de valores de vida das crianças, não só relacionados a condutas sociais, mas também vinculados a princípios e comportamentos relativos aos hábitos de vida, o que incluem a alimentação e a atividade física. Portanto, incluir a temática da educação nutricional no berço da educação de crianças, pais e professores, é fundamental para que possamos aprender a realizar escolhas alimentares saudáveis. Que disciplina teria mais utilidade do que aquela em que colocamos em prática seu conteúdo a cada refeição?

Nesta edição, a Revista Ciência \& Saúde conta com artigos que trazem à tona a emergente discussão sobre o papel do conhecimento e da educação nutricional no desenvolvimento de hábitos alimentares saudáveis, sobretudo durante a infância. Família, profissionais de saúde e escola devem estar munidos de informações corretas e estratégias para enfrentarem um dos maiores desafios de saúde: ensinar cada criança sobre a importância de uma alimentação saudável. Assim, poderemos ensinar aquilo que desaprendemos a fazer com o passar do tempo: a comer.

Boa Leitura!

Prof . Me. Raquel da Luz Dias Professora do Curso de Nutrição da FAENFI/PUCRS 